\title{
Development and Validation of a RP-HPLC Method for Simultaneous Determination of Betamethasone and Sodium Benzoate in Oral Liquid Pharmaceutical Formulation
}

\author{
MAROUA. B. ALI* ${ }^{*}$ M. ATTIA ${ }^{1}$, N. BELLILI ${ }^{1}$ AND SAMI FATTOUCH \\ Laboratory of Protein Engineering and Bioactive Molecules, National Institute of Applied Sciences and \\ Technology (INSAT), Tunisia, ${ }^{1}$ Department of Research and Development, Laboratory of Sterile Drugs \\ (Medis), Nabeul, Tunisia
}

Ali, et al.: RP-HPLC Method for Betamethasone and Sodium Benzoate

\begin{abstract}
The present work reports development and validation of a high-performance liquid chromatography diode array detection procedure for the determination of betamethasone and sodium benzoate in pharmaceutical formulation. Effective chromatographic separation of betamethasone and sodium benzoate was achieved using Nova-pack-C18 $(150 \times 3.9 \mathrm{~mm}, 4 \mu \mathrm{m})$ column with gradient elution of the mobile phase composed of 50 mM monobasic potassium phosphate buffer (pH 2.9) and acetonitrile. The elution was a three step gradient elution program with $25 \%$ acetonitrile and $75 \%$ buffer at 0 min further acetonitrile concentration changed linearly to $45 \%$ up to $25 \mathrm{~min}$, followed by changing acetonitrile to $25 \%$ up to 35 min. The correlation coefficient for betamethasone and sodium benzoate were 0.9999 and 0.9999 , respectively. The developed method was statistically validated with regard to specificity, linearity, accuracy (recovery) and precision.
\end{abstract}

Key words: Betamethasone, sodium benzoate, RP-HPLC, method validation, pharmaceutical preparation

Betamethasone is one of the representatives of the glucocorticosteroid family of steroid active pharmaceutical substance, which is used for its antiinflammatory and immunosuppressive characteristics and also as a material to produce different esters of betamethasone. Chemically, betamethasone is $(8 \mathrm{~S}, 9 \mathrm{R}, 10 \mathrm{~S}, 11 \mathrm{~S}, 13 \mathrm{~S}, 14 \mathrm{~S}, 16 \mathrm{~S}, 17 \mathrm{R})$-9-fluoro-11,17dihydroxy-17-(2-hydroxyacetyl)-10,13,16-trimethyl$6,7,8,11,12,14,15,16$-octahydrocyclopenta[a] phenanthren-3-one.

Lack of its mineralocorticoid properties makes betamethasone suitable for treating congenital adrenal hyperplasia. It prevents and controls inflammation by regulating the rate of protein synthesis. Betamethasone is also used as antibacterial agent which is not recognized in the medical field and reduces the immune reactions and is therefore, used to prevent organ transplant rejection, and also in the treatment of various disorders in which glucocorticosteroids are indicated.

Compared to tablet and capsule, liquid preparations promote a rapid absorption of active ingredient. Liquid formulations are essentially susceptible to microbial growth because of the quality of their substances. Such preparations need the use of preservatives agents to prevent chemical transformation and degradation of drug substance.

Sodium benzoate is widely used as preservative in cosmetics, foods and pharmaceutical drugs. Chemical structures of betamethasone and sodium benzoate are shown in fig. 1. Sodium benzoate is used in concentrations of $0.02-0.5 \%$ in oral medicines, $0.5 \%$ in parenteral products, and $0.1-0.5 \%$ in cosmetics ${ }^{[1]}$. It has been used for the preservation of betamethasone oral liquid formulations. The analysis of preservatives in pharmaceutical products is important to ensure quality assurance and consumer protection ${ }^{[2]}$. International Conference on Harmonization (ICH) guidance proposes that the finished product specification should include antimicrobial preservative content ${ }^{[3]}$.

This is an open access article distributed under terms of the Creative Commons Attribution-NonCommercial-ShareAlike 3.0 License, which allows other the remix, tweak, and build up to the non-commercially, as long as the author is credited and the new creations are licensed under the identical terms.

Accepted 20 Jun 2016

Revised 16 Jun 2016

Received 19 Jan 2016

*Address for correspondence

E-mail: benalimaroua@yahoo.fr

May - June 2016

Indian Journal of Pharmaceutical Sciences

402 


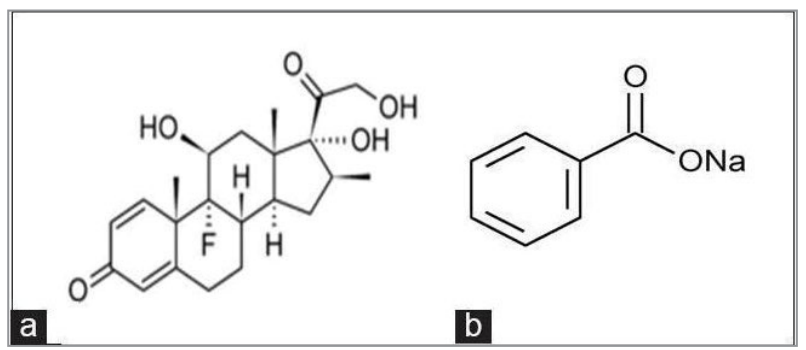

Fig. 1: Chemical structures of analytes.

a. Betamethasone $\left(\mathrm{C}_{22} \mathrm{H}_{29} \mathrm{FO}_{5}\right)$; b. sodium benzoate $\left(\mathrm{NaC}_{7} \mathrm{H}_{5} \mathrm{O}_{2}\right)$

Therefore, the analysis of betamethasone into oral drop in combination with preservative is required and essential. Literature survey reveals that the voltammetric sensor detection of betamethasone in biological fluids ${ }^{[4-5]}$, high performance liquid chromatography (HPLC) method for the determination of betamethasone ${ }^{[6]}$, for the assessment of its stability ${ }^{[7-8]}$, reverse phase sequential injection chromatography ${ }^{[9]}$, determination of betamethasone in human plasma ${ }^{[10]}$, in urine ${ }^{[11]}$ and determination related substances $^{[12]}$ were reported for the quantification of betamethasone individually and in combination with other drugs in marketed pharmaceutical formulations. Several analytical procedures have been reported for the estimation of sodium benzoate separately ${ }^{[13]}$ or in combination with other drugs by HPLC method ${ }^{[14]}$. These methods may not be suitable for simultaneous estimation of betamethasone and sodium benzoate in one chromatographic run.

To the best of our knowledge, there is no HPLC method for the simultaneous estimation of betamethasone and sodium benzoate in oral liquid formulations. In this paper, we report a simple, economical and rapid HPLC method which could serve as assay method for determination of betamethasone and sodium benzoate simultaneously in oral pharmaceutical formulation. The present method involves minimum sample preparation and reasonable analysis time due to the use of gradient elution which reduces the retention time of the two analytes. This method was successfully validated by determining its performance characteristics with regard to specificity, linearity, accuracy and precision ${ }^{[15]}$.

\section{MATERIALS AND METHODS}

HPLC system used was Waters Alliance e2695 Technology (E10SM4327A, USA) system supplied with auto sampler, quaternary pump, degasser and a PDA Detector. The output signal was monitored and processed using Empower 3 manager software. The column used was a Nova-pack $\mathrm{C}_{18}, 4 \mu \mathrm{m}$ particle
$(150 \times 3.9 \mathrm{~mm})$. The mobile phase consisted of buffer $\mathrm{pH}$ 2.9 acetonitrile in a gradient program shown in Table 1 , which was used to elute the analytes maintained at room temperature. The flow rate of the mobile phase was kept $1 \mathrm{ml} / \mathrm{min}$. Injection volume was $50 \mu \mathrm{l}$ and ultraviolet (UV) detection was set at $254 \mathrm{~nm}$.

Working standard betamethasone (99.3\%) was supplied by USP supplier (Batch No.L0G059). Sodium benzoate powder was from AppliChem PanrReac (Barcelona, Spain). Acetonitrile (HPLC grade) was purchased from Carlo Erba (Italy). Phosphoric acid, monobasic potassium phosphate and absolute ethanol were purchased from Sigma-Aldrich (Darmstadt, Germany). Water used was double distilled and filtered through $0.45 \mu \mathrm{m}$ filter. Other chemicals used were of analytical or HPLC grade.

\section{Mobile phase buffer:}

The buffer used in mobile phase was prepared by dissolving $6.8 \mathrm{~g}$ of monobasic potassium phosphate in $1000 \mathrm{ml}$ of water. The $\mathrm{pH}$ was adjusted to 2.9 with dilute phosphoric acid. The solution was filtered over $0.45 \mu \mathrm{m}$ filter.

\section{Standard solution preparation:}

The stock standard solution $(0.5 \mathrm{mg} / \mathrm{ml}$ of betamethasone and $1 \mathrm{mg} / \mathrm{ml}$ of sodium benzoate) was prepared by dissolving $50 \mathrm{mg}$ of betamethasone and $100 \mathrm{mg}$ of sodium benzoate in $40 \mathrm{ml}$ of absolute ethanol and diluting to $100 \mathrm{ml}$ with water. Standard solution was prepared by transferring $5 \mathrm{ml}$ of the standard stock solution to $50 \mathrm{ml}$ volumetric flask of diluent to get a concentration of $0.05 \mathrm{mg} / \mathrm{ml}$ for betamethasone and 0.1 $\mathrm{mg} / \mathrm{ml}$ for sodium benzoate.

\section{Sample solution preparation:}

Five millilitres of the oral liquid formulation was taken into a $50 \mathrm{ml}$ volumetric flask of diluent. The solution was prepared to achieve final concentration of 0.05 $\mathrm{mg} / \mathrm{ml}$ for betamethasone and $0.1 \mathrm{mg} / \mathrm{ml}$ for sodium benzoate.

\section{Method validation:}

TABLE 1: DESCRIPTION OF GRADIENT PROGRAM

\begin{tabular}{cccc}
\hline Step no. & $\begin{array}{c}\text { Monobasic potassium } \\
\text { phosphate buffer (\%) }\end{array}$ & $\begin{array}{c}\text { Acetonitrile } \\
\text { (\%) }\end{array}$ & $\begin{array}{c}\text { Time } \\
\text { (min) }\end{array}$ \\
\hline Step 1 & 75 & 25 & 0 \\
Step 2 & 55 & 45 & 25 \\
Step 3 & 75 & 25 & 35 \\
\hline
\end{tabular}


Concerning the assay validation, specificity was evaluated by comparing the chromatograms and the data obtained from the diluent, the placebo, the standard solution (analytes are betamethasone and sodium benzoate) and the test solution (pharmaceutical reconstituted form).

To evaluate the linearity of the proposed method, solutions were prepared at 5 spaced concentration levels which cover the interval of validation. This interval was represented by the concentrations of 60 , $80,100,120$ and $140 \%$ for the validation of the assay method. Three independent series of 5 concentrations were carried out with one series per day. The peak area values were measured for betamethasone and sodium benzoate, respectively, and plotted against the analyte concentration. This linearity was verified by the following statistical tests: Cochran test, student t-test and Fisher test.

For the evaluation of the accuracy of the developed method, five sets of samples having concentrations were prepared for each recovery level in three different days. The recovery was performed at five levels of $60,80,100,120$ and $140 \%$ of the nominal quantity in betamethasone $(50 \mu \mathrm{g} / \mathrm{ml})$ and in sodium benzoate $(100 \mu \mathrm{g} / \mathrm{ml})$. The solutions were further analyzed, and the recovery percentages between the amount/ concentration found and the amount/concentration added, the average recovery and the confidence interval were determined.

To determine the intermediate precision of the assay method, six representative test solutions with a concentration of $100 \%$ were prepared for a one day series, 18 independent values. The statistical analysis for the coefficient of variation of repeatability and the coefficient of variation of reproducibility was performed.

\section{Application of the method:}

The developed method was applied to estimate betamethasone and sodium benzoate in oral pharmaceutical formulation. The analysis of the oral liquid formulation was carried out in developing chromatographic conditions.

\section{RESULTS AND DISCUSSION}

The method validation was performed according to $\mathrm{ICH}$ guidelines for validation of analytical procedures. All samples were analyzed using the assay chromatographic conditions described previously in this work. The chromatographic parameters like number of theoretical plates, tailing factor, resolution and injection precision were evaluated for the performance of system suitability. The studied parameters were within the limits and were summarized in Table 2.

We study the specificity to ensure that there is no interference between the analytes (betamethasone and sodium benzoate) and the various products (excipients, mobile phase). For this, the diluent, the placebo solution (a mixture of all the ingredients except the two analytes), the standard solution (betamethasone and sodium benzoate) and the test solution (pharmaceutical reconstituted form) were injected separately.

After analyzing the samples by HPLC, the results were compared to ensure that there is no interference to signals from the diluent and placebo with the signals from betamethasone and sodium benzoate. The method is specific for the determination of the two analytes. The results are shown in Table 3 and fig. 2.

Linearity solutions were prepared from betamethasone $(50 \mu \mathrm{g} / \mathrm{ml})$ and sodium benzoate $(100 \mu \mathrm{g} / \mathrm{ml})$ at five different concentration levels tested from $30 \mu \mathrm{g} / \mathrm{ml}$ to $70 \mu \mathrm{g} / \mathrm{ml}$ for betamethasone (60 to $140 \%$ of the nominal quantity in betamethasone, $50 \mu \mathrm{g} / \mathrm{ml}$ ) and from $60 \mu \mathrm{g} / \mathrm{ml}$ to $140 \mu \mathrm{g} / \mathrm{ml}$ for sodium benzoate $(60$ to $140 \%$ of the nominal quantity in sodium benzoate, $100 \mu \mathrm{g} / \mathrm{ml}$ ). Linearity was determined by preparing calibration graphs. The slope, intercept of the straight line and regression equations are shown in Table 4.

The correlation coefficients between the concentration of the two analytes and detector responses are found to be higher than 0.995 . The statistical evaluation of the linearity study is presented in Table 4 . The statistical

TABLE 2: SYSTEM SUITABILITY RESULTS

\begin{tabular}{|c|c|c|c|}
\hline \multirow[t]{2}{*}{ Parameter } & \multicolumn{2}{|c|}{ Results } & \multirow[t]{2}{*}{ Required limits } \\
\hline & Betamethasone & Sodium benzoate & \\
\hline RSD of peak area & 0.19 & 0.34 & $<1.0$ for $n \geq 6$ \\
\hline RSD of retention time & 0.11 & 0.07 & $<1.0$ for $n \geq 6$ \\
\hline USP Plate Count (N) & 19698 & 5882 & $N>2000$ \\
\hline USP Tailing factor (T) & 1.02 & 1.43 & $\mathrm{~T}<2$ \\
\hline USP Resolution (R) & - & 22.87 & $\mathrm{R}>2$ \\
\hline
\end{tabular}


TABLE 3: SPECIFICITY DATA

\begin{tabular}{|c|c|c|c|c|c|}
\hline Injected solution & $\begin{array}{c}\text { Standard added to } \\
\text { placebo }\end{array}$ & $\begin{array}{c}\text { Retention time } \\
(\text { min) }\end{array}$ & Area of peak (AU) & $\begin{array}{c}\text { Theoretical } \\
\text { plates }\end{array}$ & $\begin{array}{l}\text { Symmetry } \\
\text { factor }\end{array}$ \\
\hline Diluent & - & - & - & - & - \\
\hline Placebo & - & - & - & - & - \\
\hline \multirow[t]{2}{*}{ Standard Solution } & Betamethasone & 7.936 & 417052 & 19437 & 1.02 \\
\hline & Sodium benzoate & 3.558 & 138126 & 5929 & 1.45 \\
\hline \multirow[t]{2}{*}{ Test Solution } & Betamethasone & 7.969 & 419321 & 19770 & 1.02 \\
\hline & Sodium benzoate & 3.576 & 138975 & 6096 & 1.46 \\
\hline
\end{tabular}
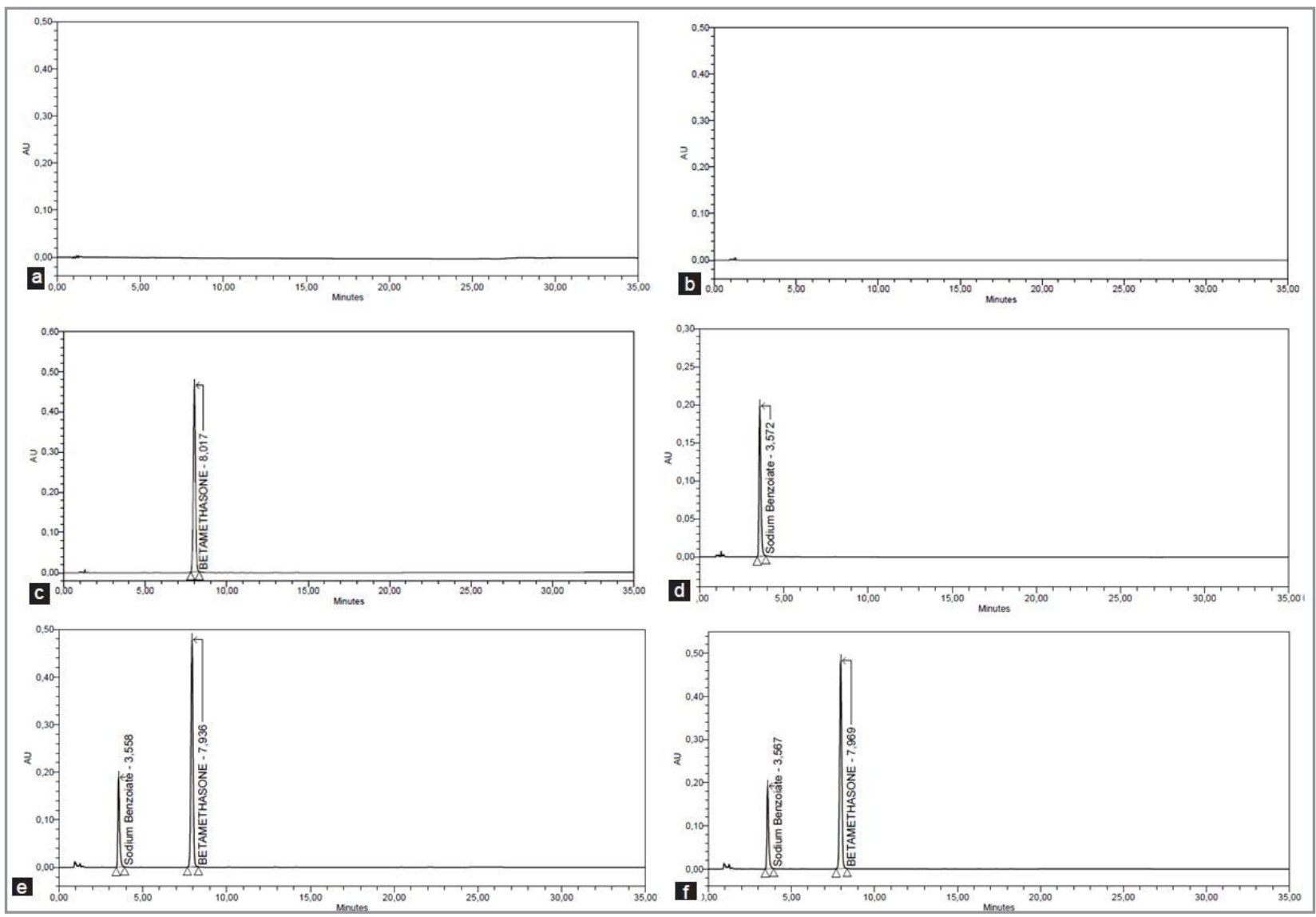

Fig. 2: Typical HPLC chromatograms of specificity.

Chromatograms of a. diluent; b. placebo solution; c. analyte 1; d. analyte 2; e. standard solution; f. test solution; retention time of betamethasone and sodium benzoate was found to be 7.95 and $3.56 \mathrm{~min}$, respectively

parameters obtained demonstrated that the method (the determination of betamethasone and sodium benzoate) has a good linearity over the considered concentrations range (fig. 3 and 4).

Accuracy is the exactness of agreement between the value which is accepted either as a conventional true value or a reference value and the value found. It is determined by comparing the found amount (concentration) with the added amount (concentration). The mean percentage recoveries were calculated for betamethasone and sodium benzoate. The results are shown in Table 5. The obtained values were found satisfactory and confirm the accuracy of the proposed method. Method accuracy was also demonstrated by plotting the concentration found of each analyte against the concentration added.

Precision expresses the closeness of agreement between a series of measurements from multiple takes of the same homogeneous sample under defined conditions. It provides an indication of random errors due. It is calculated on 3 sets of 6 measures, 100\% of theoretical concentration of the components in its product (pharmaceutical reconstituted form), on a one day series, 18 independent values. Precision is expressed by a coefficient of variation of repeatability $(\mathrm{CVr})$ and a coefficient of variation of reproducibility 
TABLE 4: STATISTICAL DATA OF THE LINEARITY OF BETAMETHASONE AND SODIUM BENZOATE

\begin{tabular}{lcc}
\hline Parameters & Betamethasone & Sodium benzoate \\
\hline Linearity range $(\mu \mathrm{g} / \mathrm{ml})$ & $30-70$ & $60-70$ \\
Slope & 83946.8 & 13752.7 \\
y-intercept & -39570.8 & +5542.7 \\
Correlation coefficient & 0.999 & 0.999 \\
Regression equation & $83946 x-39570$ & $13751 \times+5542$ \\
Student's t-test- Comparison of the intercept with 0 (should be not more than 2.164) & 2.0491 (NS) & 0.8764 (NS) \\
Cochran Test - Homogeneity of variances (should be not more than 0.6838) & 0.4613 (NS) & 0.4929 (NS) \\
Fisher Test - Significant slope (should be not more than 4.67) & 86465 (S) & 53297 (S) \\
Fisher Test - Validity of regression line (should be not more than 3.71) & 2.84 (NS) & 1.25 (NS) \\
\hline
\end{tabular}

NS: Not significant test, S: significant test
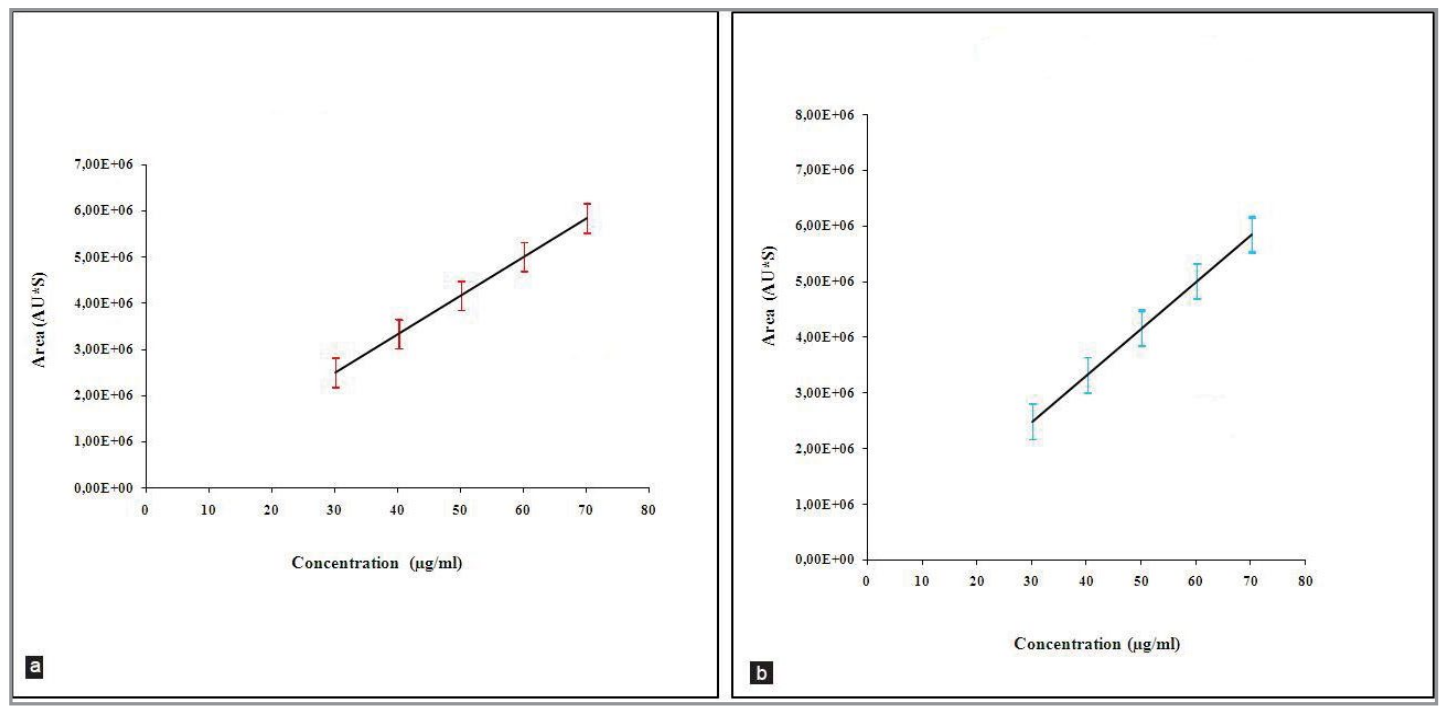

Fig. 3: Calibration curve of betamethasone .

a. calibration curve of betamethasone in standard solution and $b$. in pharmaceutical reconstituted form solution; regression equation was $y=83483 x-14770$ and $y=83946 x-39570$, respectively. Correlation coefficient were found to be $R^{2}=1$ and $R^{2}=0.999$, respectively.

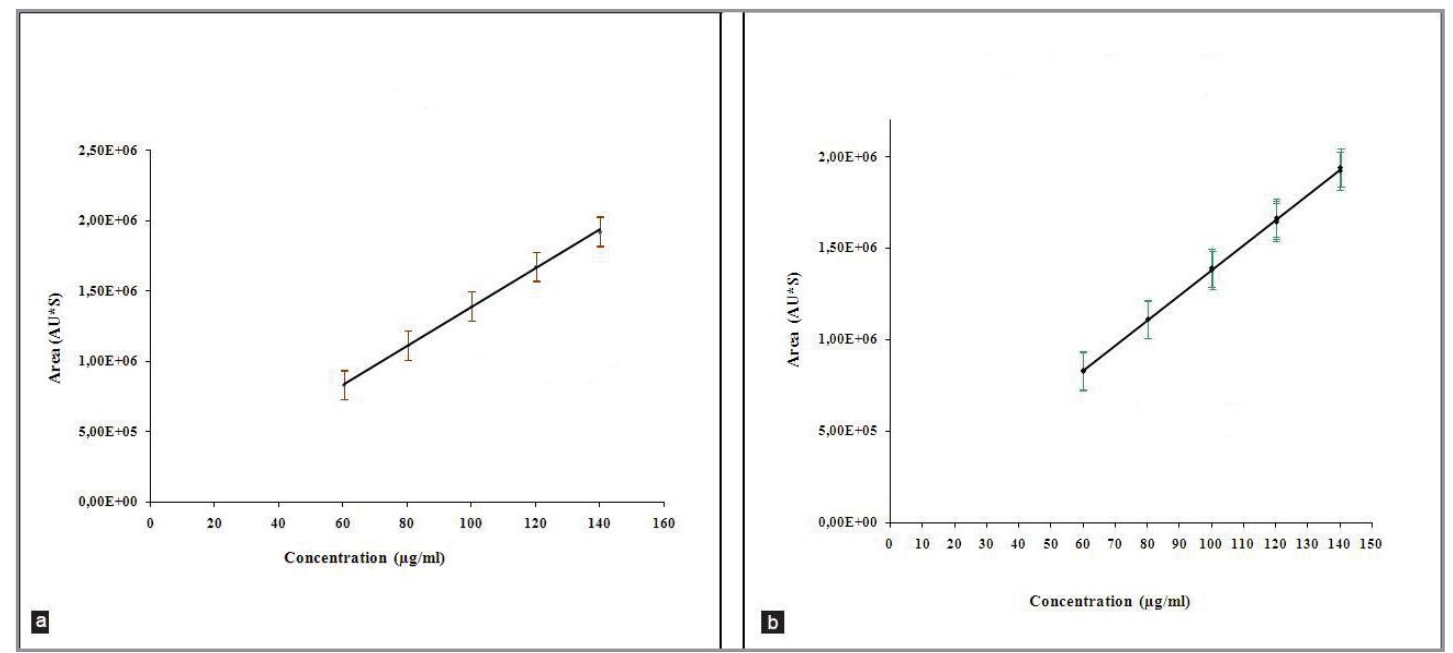

Fig. 4: Calibration Curve of sodium benzoate

a. Calibration curve of sodium benzoate in standard solution and b. in pharmaceutical reconstituted form solution; regression equation were $y=13729 x+11643$ and $y=13752 x+5542.7$, respectively. Correlation coefficient were found to be $R^{2}=0.9994$ and $\mathbf{R}^{2}=\mathbf{0 . 9 9 9 7}$, respectively.

(CVR). The approach of the statistical analysis is to demonstrate statistically that the method is repeatable and reproducible. Results are shown in Table 6. The results of the precision study indicate that the method of assay of betamethasone and sodium benzoate is precise $(\mathrm{CVr}<2 \%$ and $\mathrm{CVR}<2 \%)$. 
TABLE 5: ACCURACY DATA OF BETAMETHASONE AND SODIUM BENZOATE

\begin{tabular}{ccccc}
\hline Recovery level (\%) & $\begin{array}{c}\text { Standard added to } \\
\text { placebo }\end{array}$ & $\begin{array}{c}\text { Total concentration }(\boldsymbol{\mu g} / \\
\mathbf{m l})\end{array}$ & $\begin{array}{c}\text { Found concentration } \\
(\boldsymbol{\mu g} / \mathbf{m l})\end{array}$ & Mean recovery (\%) \\
\hline 60 & Betamethasone & 30 & 30.15 & 99.65 \\
& Sodium benzoate & 60 & 60.25 & 99.09 \\
80 & Betamethasone & 40 & 40.19 & 99.44 \\
& Sodium benzoate & 80 & 80.27 & 99.79 \\
100 & Betamethasone & 50 & 50.16 & 100.24 \\
& Sodium benzoate & 100 & 100.17 & 100.07 \\
120 & Betamethasone & 60 & 60.17 & 100.13 \\
& Sodium benzoate & 120 & 120.16 & 99.51 \\
140 & Betamethasone & 70 & 70.14 & 100.02 \\
& Sodium benzoate & 140 & 140.18 & 99.87 \\
\hline
\end{tabular}

TABLE 6: PRECISION DATA OF BETAMETHASONE AND SODIUM BENZOATE

\begin{tabular}{ccccc}
\hline Group & $\begin{array}{c}\text { Standard added to } \\
\text { placebo }\end{array}$ & Added concentration $(\mu \mathrm{g} / \mathrm{ml})$ & $\begin{array}{c}\text { Found mean } \\
\text { concentration }(\mu \mathrm{g} / \mathrm{ml})\end{array}$ & Mean recovery $(\%)$ \\
\hline 1 & Betamethasone & 50 & 50.24 & 100.21 \\
& Sodium Benzoate & 100 & 100.17 & 99.99 \\
2 & Betamethasone & 50 & 50.22 & 100.08 \\
& Sodium Benzoate & 100 & 100.21 & 99.96 \\
3 & Betamethasone & 50 & 50.18 & 100.24 \\
& Sodium Benzoate & 100 & 100.19 & 100.35 \\
& $\mathrm{CVr}(\%)$ & Betamethasone & 0.22 & \\
& CVR (\%) & Sodium Benzaote & 0.39 & \\
& & Betamethasone & 0.24 & \\
& & Sodium Benzaote & 0.42 & \\
\hline
\end{tabular}

The results of the analysis of oral liquid pharmaceutical formulation using the proposed method are shown in Table 7. The developed method was successfully applied to analyze betamethasone and sodium benzoate in oral liquid formulation.

In this work, a novel RP-HPLC method has been developed for the simultaneous determination of betamethasone and sodium benzoate in oral pharmaceutical formulation. To our present knowledge, no attempts have yet been made to estimate the two analytes simultaneously by any analytical methodology. The method was validated and shown satisfactory results for all method-validated parameters. Therefore, the developed method can be used as regular quality control analysis for the determination of betamethasone and sodium benzoate in oral pharmaceutical formulation.

\section{Acknowledgements:}

This project is in the framework of a Doctoral thesis MOBIDOC belonging to the PASRI program which is financed by the EU and managed by the ANPR. The authors gratefully acknowledge the members of the Research and Development Department at Medis
TABLE 7: ASSAY RESULT OF BETAMETHASONE AND SODIUM BENZOATE IN ORAL LIQUID FORMULATION

\begin{tabular}{ccc}
\hline Compound & $\begin{array}{c}\text { Theoretical content } \\
(\%)\end{array}$ & $\begin{array}{c}\text { Found content } \\
(\%)\end{array}$ \\
\hline Betamethasone & $90.0-115.0$ & 101.5 \\
Sodium benzoate & $90.0-110.0$ & 100.04 \\
\hline
\end{tabular}

Laboratories for their encouragement and support to carry out this work.

\section{Financial support and sponsorship:}

Nil.

\section{Conflicts of interest:}

There are no conflicts of interest.

\section{REFERENCES}

1. Rowe RC, Sheskey PJ, Quinn ME, editors. Handbook of pharmaceutical excipients. 6th ed. London: Pharmaceutical Press; 2009.

2. Boukarim C, Abou Jaoude S, Bahnam R, Barada R, Kyriacos S. Preservatives in liquid pharmaceutical preparations. J Appl Res 2009;1:146-8. 
3. Food Drug Administration. International Conference on Harmonisation: guidance on Q1D bracketing and matrixing designs for stability testing of new drug substances and products. Fed Regist 2003;68:2339-40.

4. Goyal RN, Bishnoi S, Rana AR. A sensitive voltammetric sensor for detecting betamethasone in biological fluids. Comb Chem High Throughout Screen 2010;13:610-8.

5. Petersen MC, Nation RL, Ashley JJ. Simultaneous determination of betamethasone, betamethasone acetate and hydrocortisone in biological fluids using high-performance liquid chromatography. J Chromatogr 1980;183:131-9.

6. Ankam R, Mukkanti K, Durgaprasad S, Khan M. Simultaneous HPLC determination of butenafine hydrochloride and betamethasone in a cream formulation. Indian $\mathrm{J}$ Pharm Sci 2009; 71:547-51.

7. $\mathrm{Fu} \mathrm{Q}$, Shou M, Chien D, Markovich R, Rustum AM. Development and validation of a stability-indicating RPHPLC method for assay of betamethasone and estimation of its related compounds. J Pharm Biomed Anal 2010;51:617-25.

8. Xiong Y, Xiao KP, Rustum AM. Development and validation of a stability-indicating RP-HPLC method to separate low levels of dexamethasone and other related compounds from betamethasone. J Pharm Biomed Anal 2009;49:646-54.

9. Satinsky D, Chocholous P, Salabova M, Solich P. Simple determination of betamethasone and chloramphenicol in a pharmaceutical preparation using a short monolithic column coupled to a sequential injection system. J Sep Sci 2006;29:2494-9.

10. Pereira Ados S, Oliveira LS, Mendes GD, Gabbai JJ, De Nucci G. Quantification of betamethasone in human plasma by liquid chromatography-tandem mass spectrometry using atmospheric pressure photoionization in negative mode. J chromatogr B Analyt Technol Biomed Life Sci 2005;828:27-32.

11. Polettini A, Marrubini Bouland G, Montagna M. Development of a coupled-column liquid chromatographic-tandem mass spectrometric method for the direct determination of betamethasone in urine. J Chromatogr B Biomed Sci Appl 1998;713:339-52.

12. Arthur KE, Wolff JC, Carrier DJ. Analysis of betamethasone, dexamethasone and related compounds by liquid chromatography/electrospray mass spectrometry. Rapid Comm Mass Spectrom 2004;18:678-84.

13. Zhang H, Qi L, Qiao J, Mao L. Determination of sodium benzoate by chiral ligand exchange $\mathrm{CE}$ based on its inhibitory activity in D-amino acid oxidase mediated oxidation of D-serine. Anal Chim Acta 2011;691:103-9.

14. Kumar N, Sangeetha D, Reddy PS, Prakash L. A Validated Stability-Indicating RP-UPLC Method for Simultaneous Determination of Desloratadine and Sodium Benzoate in Oral Liquid Pharmaceutical Formulations. Sci Pharm 2012;80:153-65.

15. Guideline for Industry. Text on Validation of Analytical Procedures, United States, March, 1995. 